\title{
Analysis of polyethoxylated ascorbic acid using spectrophotometry
}

\section{Zhexue Wu${ }^{1}$ Kwang-Hyeon Liu $^{1}$ (D) \\ 분광광도계를 이용한 폴리에톡시레이티드 아스코르빈산 분석법 개발}

\author{
오철학 ${ }^{1}$ 류광현 ${ }^{1}$
}

Received: 5 September 2016 / Accepted: 12 September 2016 / Published Online: 31 December 2016

(C) The Korean Society for Applied Biological Chemistry 2016

\begin{abstract}
We developed a spectrophotometric assay method for polyethoxylated ascorbic acidusing 3-ethyl ascorbic acid as standard material. The analytical method was validated by linearity, accuracy, precision, and stability. The coefficient of variation of the precision of the assay was less than $3.4 \%$. The linearity of the calibration curves in the desired concentration range is good $\left(r^{2}>0.998\right)$. 3-Ethyl ascorbic acid and polyethoxylated ascorbic acid were stable in stock solution at room temperature for up to at least $6 \mathrm{~h}$. The developed assay could be used for the content analysis of polyethoxylated ascorbic acid in samples.
\end{abstract}

Keywords Accuracy · Polyethoxylatedascorbic acid · Precision - Spectrophotometry $\cdot$ Validation

\section{서 론}

비타민 C (L-아스코르빈산, L-ascorbic acid)는 대부분 동물들이 체내에서 합성할수 있지만 인간, 설치류, 어류는 체내에 비타민 $\mathrm{C}$ 를 합성하는 효소가 결핍하여 반드시 음식으로부터 섭취하여

Kwang-Hyeon Liu $(\bowtie)$

E-mail:dstlkh@knu.ac.kr

${ }^{1}$ BK21 Plus KNU Multi-Omics based Creative Drug Research Team, College of Pharmacy and Research Institute of Pharmaceutical Sciences, Kyungpook National University, Daegu 41566, Republic of Korea

This is an Open Access article distributed under the terms of the Creative Commons Attribution Non-Commercial License (http://creativecommons. org/licenses/by-nc/3.0/) which permits unrestricted non-commercial use, distribution, and reproduction in any medium, provided the original work is properly cited.
야 한다(Wilson 1973). 비타민 C는 면역 증강제로서 세포 대사 과정 중에 산화-환원 반응에서 중요한 작용을 하고 골격근의 유 지와 생성에서도 중요한 역할을 한다. 이외에 비타민 $\mathrm{C}$ 는 세포 내의 중요한 항산화 작용과 free radical을 빠르게 억제하는 역 할을 한다. 최근 연구 결과에 의하면, 닭 사료에 첨가된 비타민 $\mathrm{C}$ 는 지방 산패도를 감소시키고(Kang 등, 2007) 부분육중 가슴 육의 생산량을 증가시키는 효과를 나타내었다(Kang 등, 2015). 또한 가금류에 비타민 $\mathrm{C}$ 급여 시스트레스를 경감시킨다는 많은 연구 결과들이 보고되고 있다(Kang 등, 2007; Park 등, 2013). 양어의 경우 사료 내에 비타민 $\mathrm{C}$ 를 첨가하였을 때 어류의 성 장, 콜라겐 합성, 면역활성, 질병저항성과 스트레스 저항성을 향 상시키는 효과가 보고되었다(Eo와 Lee 2008; Zhou 등, 2012). 따라서 비타민 $\mathrm{C}$ 는 현재 가금류 및 어류의 사료 첨가물로 널 리 사용되고 있다.

그러나, 비타민 $\mathrm{C}$ 는 가격이 비싸고 빛, 온도, 수분과 같은 환 경적인 요인에 의해 쉽게 분해되는 단점을 가지고 있다(el Naggar and Lovell 1991). 비타민 C의 열 안정성을 개선하기 위하여 굴로노락톤(gulono- $\gamma$-lactone), 토코페롤 및 코지산(kojic acid) 등이 비타민 $\mathrm{C}$ 의 2 번 또는 3번 탄소에 결합한 다양한 비 타민 C 유도체가 합성되었다(Morisaki and Ozaki 1996; Olabisi 등, 2005). 현재 시중에서유통되고 있는 비타민C 제품은 황산 화제품(L-Ascorbyl-2-sulfate)과 인산화제품(Magnesium ascorbate phosphate) 등이 사용되고 있고, 이중 황산화제품은 생체내에 분 해효소인술파타아제(sulfatase)가 부족함으로 많이 사용되지 않고 인산화 제품은 안정하지만 가격이 비싼 단점이 있다(Song 등, 2013).

최근 폴리에틸렌글리콜과 비타민 $\mathrm{C}$ 와의 결합을 통하여 개발 된 폴리에톡시레이티드 아스코르빈산(Fig. 1)은 높은 열 안정성 과 항산화활성을 나타내어 돼지 및 닭에 비타민 $\mathrm{C}$ 를 공급하기 위한 사료 첨가제로 가축에 사용되고 있다(Song 등, 2000). 또 한, 화장품 연구에서는 폴리에톡시레이티드 아스코르빈산이 멜 라닌(melanin)의 합성 효소인티로시나아제(tyrosinase)에 대해 높 
<smiles>COCC(C)(C)OCC(C)(C)OC1=C(O)C(=O)OC1C(O)CO</smiles>

Fig. 1 Chemical structure of polyethoxylated ascorbic acid

은 억제능을 보였다(Song 등, 2000). 본 연구에서는 제품 중 폴 리에톡시레이티드 아스코르빈산의 함량 분석을 위해 필요한 분 석법을 개발하고 분석법 검증을 수행하여 공인 분석법을 개발 하고자 하였다.

\section{재료 및 방법}

\section{시약 및 재료}

3-Ethyl ascorbic acid 표준품(분자량=204.18, 99.23\%), 폴리에 톡실레이티드 아스코르빈산(MED-C, 평균 분자량=508) 및 Poustin-C (LOT NO. MEC16004, MEC16005 및 MEC160408, CTCBIO Inc., Hongcheon, Korea)는 LG Life Sciences에서 분양 받았다. 아세토니트릴(acetonitrile) 및 물은 HPLC급을 구 매하여 사용하였다(Merck, Germany).

\section{표준용액 및 검액의 제조}

3-Ethyl ascorbic acid 표준품을 각각 $5,15,25,35,45,55$ 및 $65 \mathrm{mg}$ 을 정확하게 칭량하여 $100 \mathrm{~mL}$ 용량 플라스크(volumetric flask)에 넣고 $5 \%$ 아세토니트릴 수용액으로 용해한 후 동일 희 석액으로 표선까지 맞추었다. 각 표준용액 $2 \mathrm{~mL}$ 를 $100 \mathrm{~mL}$ 용 량 플라스크에 넣고 희석액을 표선까지 넣어 희석하였다.

MED-C $60 \mathrm{mg}$ 과 Posutin-C $240 \mathrm{mg}$ 을 정확하게 칭량하여 각 각 $100 \mathrm{~mL}$ 용량 플라스크에 넣고 희석액으로 표선까지 맞추었 다. 각 시료 용액 $5 \mathrm{~mL}$ 를 용량 플라스크에 옮기고 희석액으로 표선한다. 용액 $5 \mathrm{~mL}$ 을 $100 \mathrm{~mL}$ 용량 플라스크에 넣고 희석액 을 표선까지 넣어 희석하였다. 한 개의 검체 당 3 개의 검액을 각각 조제하였다.

\section{검량선 작성 및 정량분석}

각각의 표준용액 및 검액 중 3-ethyl ascorbic acid의 농도는 자 외선 분광광도계(UV spectrophotometer, Shimadzu UV-1800, Kyoto, Japan) 를 사용하여, 파장 $244 \mathrm{~nm}$ 에서 흡광도를 측정하 였다. 검액중에서 측정된 흡광도 값을 미리 작성한 검량선에 적 용하여 검체 중 3-ethyl ascorbic acid의 농도를 구한 후, 아래 식을 이용하여 검체 중 폴리에톡실레이티드 아스코르빈산의 함 량을 계산하였다.검체의 순도는 농림축산식품부 공고 제2016168호에 있는 L-아스콜빈산-2-폴리에틸렌 글리콜 에테르 (polyethoxylated ascorbic acid)의 순도 계산법을 이용 측정하였 다(Ministry of Agriculture, Food and Rural Affairs 2016).

$$
\begin{aligned}
\text { 함량 }(\%)= & \frac{3 \text {-Ethyl ascorbic acid 중량 } \times \text { 표준품순도 }(0.9923)}{\text { 검체중량ㄱ검체순도 }} \\
& \times \frac{\text { 폴리에톡시레이티드아스코르빈산분자량 }(508)}{3 \text {-Ethyl ascorbic acid 분자량 }(204.18)} \div 2.5 \times 100
\end{aligned}
$$

\section{분석법 검중}

3-Ethyl ascorbic acid 표준용액을 이용하여 직선성, 정확성 및 정밀성, 안정성 등을 측정하였다. 직선성은 검량선을 4 회 반복 작성하고, 각 검량선의 기울기 $(a)$ 와 상관계수(coefficient of correlation, $\left.r^{2}\right)$ 를 구하여 평가하였다. 정확성 $(\%)$ 과 정밀성 (coefficient of variation, $\mathrm{CV}$ )은 하루에 실험을 4번 시행하여 일내(intraday) 정밀성 및 정확성을 구하였고, 4 일간 실험을 반 복 수행하여 일간(interday) 정밀성 및 정확성을 구하였다.

3-Ethyl ascorbic acid 및 폴리에톡실레이티드 아스코르빈산의 빛에 대한 안정성을 평가하기 위하여, 3-ethyl ascorbic acid 20 $\mathrm{mg}$ 및 폴리에톡실레이티드 아스코르빈산 $60 \mathrm{mg}$ 을 칭량하여 100 $\mathrm{mL}$ 용량 플라스크에 넣고 희석액으로 표선까지 맞추었다. 각각 의 용액 $2 \mathrm{~mL}$ 및 $5 \mathrm{~mL}$ 을 $100 \mathrm{~mL}$ 용량 플라스크에 넣고 희석 액을 표선까지 넣어 희석하였다. 이 후, 각 용액을 실온에서 1 , 3,6 시간 방치한 후 0 시간 방치 시료와 비교하여 안정성을 평 가하였다 $(n=3)$.

\section{결과 및 고찰}

\section{분광광도 분석법의 확립}

검체중에 존재하는 활성성분의 함량 분석법은 간단하면서도 비 용이 저렴한 시험 방법이 바람직하다. 본 연구에서는 실험실에 서 쉽게 사용할 수 있는 분광광도계를 이용하여 검체 중에 활 성성분의 함량 분석법을 개발하였다. 폴리에톡실레이티드 아스 코르빈산은 단일화합물이 아니고 순수 분리도 용이하지 않아 비 타민 C 그룹을 가지고 있는 3-ethyl ascorbic acid를 표준 검량

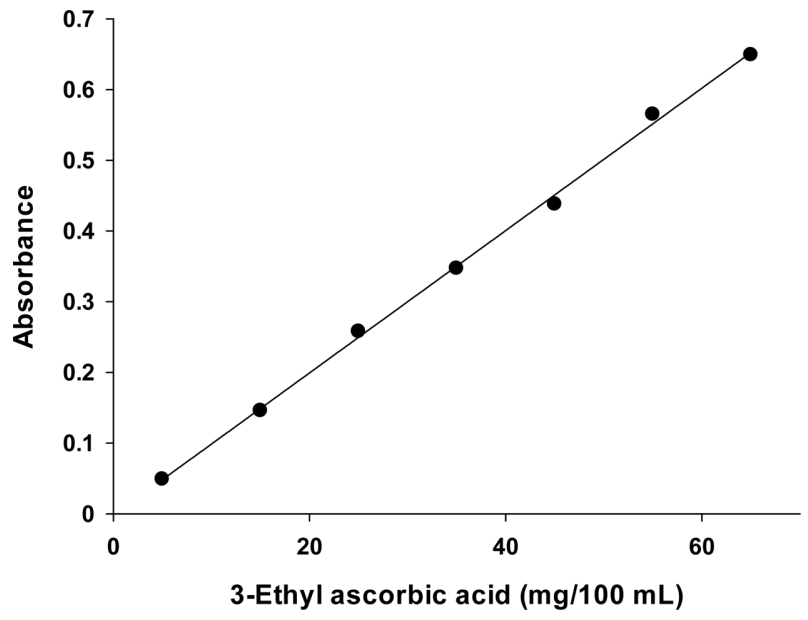

Fig. 2 Calibration curve for 3-ethyl ascorbic acid 
Table 1 Day-to-day linear regression equation for 3-ethyl ascorbic acid

\begin{tabular}{cccc}
\hline \multirow{2}{*}{ Component } & \multicolumn{3}{c}{$y=a x+b\left(r^{2}\right)^{\mathrm{a}}$} \\
\cline { 2 - 4 } & $a$ & $b$ & $r^{2}$ \\
\hline Intra-day & $0.010 \pm 0.001$ & $-0.002 \pm 0.002$ & $0.999 \pm 0.001$ \\
Inter-day & $0.010 \pm 0.001$ & $-0.002 \pm 0.002$ & $0.998 \pm 0.002$ \\
\hline
\end{tabular}

${ }^{a} y$ : peak areas, $x$ : concentration, $r^{2}$ : correlation coefficient, data: averages \pm standard deviation $(n=4)$

Table 2 Precision and accuracy of the intraday and interday assay of 3 ethyl ascorbic acid

\begin{tabular}{ccccc}
\hline \multirow{2}{*}{$\begin{array}{c}\text { Added } \\
(\mathrm{mg} / 100 \mathrm{~mL})\end{array}$} & \multicolumn{2}{c}{ Intra-day } & \multicolumn{2}{c}{ Inter-day } \\
\cline { 2 - 5 } & Accuracy $^{\mathrm{a}}$ & $\mathrm{CV}(\%)$ & Accuracy $^{\mathrm{a}}$ & $\mathrm{CV}(\%)$ \\
\hline 5 & $103.4 \pm 3.0$ & 2.9 & $96.9 \pm 3.3$ & 3.4 \\
25 & $102.3 \pm 0.5$ & 0.5 & $102.6 \pm 1.6$ & 1.5 \\
45 & $97.3 \pm 0.8$ & 0.8 & $96.0 \pm 2.1$ & 2.2 \\
65 & $100.0 \pm 0.7$ & 0.7 & $100.9 \pm 0.4$ & 0.4 \\
\hline
\end{tabular}

${ }^{\mathrm{a}}$ Data: average $\% \pm$ standard deviation $(\mathrm{SD})$

$\mathrm{CV}($ coefficient of variation $)=(\mathrm{SD} /$ average $) \times 100$

Table 3 Indoor light stability of 3-ethyl ascorbic acid and polyethoxylated ascorbic acid

\begin{tabular}{ccc}
\hline & \multicolumn{2}{c}{$\%$ of control } \\
\cline { 2 - 3 } Time (h) & $\begin{array}{c}\text { 3-ethyl ascorbic acid } \\
(20 \mathrm{mg} / 100 \mathrm{~mL})\end{array}$ & $\begin{array}{c}\text { MED-C }^{\mathrm{a}} \\
(60 \mathrm{mg} / 100 \mathrm{~mL})\end{array}$ \\
\hline 1 & $102.69 \pm 0.95$ & $99.11 \pm 0.66$ \\
3 & $101.18 \pm 1.45$ & $104.03 \pm 1.31$ \\
6 & $101.51 \pm 0.71$ & $95.37 \pm 0.39$ \\
\hline
\end{tabular}

data: averages \pm standard deviation $(n=3)$

Table 4 Polyethoxylated ascorbic acid content analysis in Poustin-C samples

\begin{tabular}{ccc}
\hline Poustin-C Lot \# & Purity (\%) & Assay $(\mathrm{w} / \mathrm{w} \%)^{\mathrm{a}}$ \\
\hline MEC16004 & 91.91 & $14.95 \pm 0.27$ \\
MEC16005 & 91.81 & $14.87 \pm 0.21$ \\
MEC160408 & 91.88 & $14.82 \pm 0.52$ \\
Average & 91.87 & $14.91 \pm 0.52$ \\
\hline
\end{tabular}

adata: averages \pm standard deviation $(n=3)$

선 작성을 위한 표준품으로 사용하였다. 3-Ethyl ascorbic acid 의 UV 스펙트럼 분석 결과, $244 \mathrm{~nm}$ 에서 최대흡수를 보였기 때 문에 $244 \mathrm{~nm}$ 에서 표준용액의 흡광도를 측정하여 표준 검량선을 작성하였다. 3-Ethyl ascorbic acid $5 \sim 65 \mathrm{mg} / 100 \mathrm{~mL}$ 의 농도 범 위에서 작성된 평균검량선은 $y$ (흡광도) $=0.010 x$ (농도) -0.002 $\left(r^{2}>0.998\right)$ 로 직선성이 매우 우수하였다(Fig. 2). 분석법의 정밀 성을 나타내는 검량선의 기울기와 상관계수 값의 변동계수 $(\mathrm{CV})$ 는 각각 10.0 및 $0.2 \%$ 이하로 매우 우수하였다(Table 1) (Liu 등, 2001).

분석법 검증을 위하여 일내 및 일간, 4단계의 농도로 정확성 을 평가하였다. 일중(intraday) 정확도는 97.3 103.4\%의 범위 안에 해당하였고, 일간(interday) 정확도는 96.0 102.6\%의 범위 를 나타내었다(Table 2). 정확도와 함께 네 가지 농도 수준에서 일내 및 일간에 따른 변동계수 $(\%, \mathrm{CV})$ 를 계산하여 정밀성을 평
가하였다. 일내 변이계수는 $0.5 \sim 2.9 \%$ 였고, 일간 변이계수는 $0.4 \sim 3.4 \%$ 의 범위 안에 해당하는 값을 나타내어(Table 2), 식품 의약품안전처의 “생체시료분석법 밸리데이션 해설서”의 허용 변 동계수 $(\leq 15 \%)$ 이내에 들어 적합한 분석방법이라고 할 수 있다 (Ministry of Food and Drug Safety 2010).

\section{실온 안정성 평가}

비타민 C는 빛에 불안정하기 때문에(el Naggar and Lovell 1991), 비타민 C 유도체로 실험에서 표준물질로 사용된 3-ethyl ascorbic acid와 Poustin-C 검체 내 활성물질인 폴리에톡시레이 티드 아스코르빈산의 분석 과정 중 안정성을 평가하기 위하여 실온 안정성 시험을 실시하였다. 이들 물질을 실온에서 1,3 및 6 시간 방치한 후 분석을 실시하여 대조군인 0 시간 시료와 비교 하였을 때, 대조군과 $5 \%$ 미만의 차이를 보여 6시간까지 실온 조건에서 안정함을 확인할 수 있었다(Table 3). 이는 분석을 진 행하는 과정에 검량선 표준물질과 제품이 안정함을 의미한다.

\section{함량분석}

본 연구에서 확립된 분광광도계를 이용한 폴리에톡시레이티드 아스코르빈산 분석법을 이용하여, 가축용 보조제로 사용되고 있 는 Poustin-C 검체 내 폴리에톡시레이티드 아스코르빈산 함량 분석을 수행하였다. 그 결과, 검체 내 폴리에톡시레이티드 아스 코르빈산 함량은 평균 $14.91 \%$ 로 Poustin-C 제품의 함량 기준 인 $14.5 \%$ 이상으로 확인되었다(Table 4 ).

\section{초 록}

본 연구에서는 3-ethyl ascorbic acid를 표준물질로 이용하여, 폴 리에톡시레이티드 아스코르빈산의 정량법을 개발하였고, 확립된 시험법으로 시중에서 돼지 및 닭의 면역력 증진과 열에 대한 스트레스 경감제로 유통되고 있는 Poustin-C 검체 내 폴리에톡 시레이티드 아스코르빈산의 함량 분석을 실제로 분석하여 시험 법의 유효성을 검증하였다. 개발한 분석법의 검증은 직선성, 정 확성, 정밀성 및 안정성 시험 등을 통하여 평가하였다. 정밀도 시험은 일내 정밀성과 일간 정밀성으로 나누어 확인하였는데, 일내 및 일간 정밀성은 모두 $3.4 \%$ 이내로 매우 우수하였다. 그 리고 직선성 실험에서는 상관계수 $\left(r^{2}\right)$ 가 0.998 이상으로 우수하 였다. 실온에서 6시간까지는 안정하여 실험 도중 분해되지 않 음을 확인하였다. 따라서 본 연구에서 개발된 시험법은 검체 내 폴리에톡시레이티드 아스코르빈산의 함량을 분석하기 위한 공 정 시험법으로 활용할 수 있을 것으로 사료된다.

Keywords 검증 - 분광광도계 - 정밀도 - 정확도 - 폴리에톡시레 이티드 · 아스코르빈산

\section{References}

el Naggar GO, Lovell RT (1991) L-ascorbyl-2-monophosphate has equal antiscorbutic activity as L-ascorbic acid but L-ascorbyl-2-sulfate is inferior to L-ascorbic acid for channel catfish. J Nutr 121: 1622-1626 Eo J, Lee KJ (2008) Effect of dietary ascorbic acid on growth and non- 
specific immune responses of tiger puffer, Takifugu rubripes. Fish \& shellfish immunology 25: 611-616

Kang HK, Kim J-H, Jong H, Kim CH (2015) Effects of Dietary Supplementation of Vitamin C and Sea Buckthorn on the Performance and Meat Quality in Old Laying Hens. Korean J Poult 42: 181-189

Kang HK, Kim SH, Kim JH, Kang GH, Yu DJ, Na JC, Kim DW, Seo OS, Kim GH, Kim GH, Park BS (2007) Effects of Dietary Fish Oil, Vitamin E and C Supplementation on DHA Deposition and Shelf-Life in Broiler Chickens. Korean J Poult 34: 259-269

Liu KH, Byoun JY, Sung HJ, Lee HK, Kim K, Lee HS, Kim JH (2001) Simultaneous determination of furathiocarb and metabolites in biological tissues by high-performance liquid chromatography and post-column derivatization. Chromatographia 53: 687-690

Ministry of Agriculture, Food and Rural Affairs (2016) The notice of Ministry of Agriculture, Food and Rural Affairs 2016-168, Sejong

Ministry of Food and Drug Safety (2010) Guideline on Bioanalytical Method Validation, Sejong

Morisaki K, Ozaki S (1996) Design of novel hybrid vitamin C derivatives: thermal stability and biological activity. Chem Pharm Bull 44: 16471655
Olabisi AO, Mahindaratne MP, Wimalasena K (2005) A convenient entry to $\mathrm{C} 2$ - and $\mathrm{C} 3$-substituted gulono-gamma-lactone derivatives from Lascorbic acid. The J Org Chem 70: 6782-6789

Park JG, An YS, Sohn SH, Jang IS, Moon YSM (2013) The Effects of Dietary Supplementation of Vitamin C or E on the Expressions of Endoplasmic Reticulum Stress, Lipid and Glucose Metabolism Associated Genes in Broiler Chickens. Korean J Poult 40: 147-155

Song J-W, Park S-H, Lee C-R, Lee K-J (2013) Effects of Dietary Supplementation of a Citrus By-product on Growth Performance, Innate Immunity and Tolerance of Low Water Temperature in Red Seabream Pagrus major. Kor J Fish Aquat Sci 46: 399-406

Song Y-S, Chung B-Y, Cho W-G, Kang S-H (2000) Development of Polyethoxylated Ascorbic Acid as a Whitening Agent. J Soc Cosmet Sci Korea 35: 199-211

Wilson RP (1973) Absence of ascorbic acid synthesis in channel catfish, Ictalurus punctatus and blue catfish, Ictalurus frucatus. Comp Biochem Physiol B 46: 635-638

Zhou Q, Wang L, Wang H, Xie F, Wang T (2012) Effect of dietary vitamin C on the growth performance and innate immunity of juvenile cobia (Rachycentron canadum). Fish Shellfish Immunol 32: 969-975 